\title{
The First Written Communist Constitutions in China and Hungary and the Influence of the 1936 Soviet Constitution: A Comparative Perspective
}

\author{
$\mathrm{DA}_{\mathrm{A}} \mathrm{LU}^{*}$
}

\begin{abstract}
Following World War II, a series of Conferences were held among the great powers. Hungary, along with its neighboring countries, had to join the socialist bloc and transformed itself into a socialist system. The Communist Party adopted the communist Constitution as soon as they won the parliamentary election. In the Far East, the Chinese Communist Party also promulgated its Constitution after the first election of the National People's Republic. In this article, the author will firstly examine how the Constitution adopted between China and Hungary followed by a comparative analysis of the two Constitutions will be employed. The author will give special attention on the text and structure of the Constitution in the respective countries. In the end, the relations with Soviet Union between China and Hungary influenced the two Constitutions will be considered.
\end{abstract}

Keywords: First Written Communist Constitution; China; Hungary; 1936 Soviet Constitution; Comparative Perspective.

The Soviet Union had the chance to develop its sphere of influence in the Central and Eastern Europe ${ }^{1}$ following the Second World War and the weakness of capitalism in Europe. ${ }^{2}$ In Asia, Japan lost control in East Asia and the Chinese Communist Party defeated its main enemy, Kuomintang (Chinese Nationalist Party). China with the help of Soviet Union, established its own communist regime in 1949. People's Republic of China and Hungary witnessed a communist tide in 1940s.

The People's Republic of China was established in 1949, after five years ruling and the majority of territory of China was controlled by People's Republic of China. The Chinese government published Electoral Law of People's Republic of China in 1953 in order to adopt the Constitution of People's Republic of China ${ }^{3}$ with the first National People's Congress formed after the nationwide election. After a long-term discussion on the Constitution, the first Constitution of People's Republic of China was adopted by the first National People's Congress. This was validated until 1975.

* Da Lu, PhD in Law. Postdoc research fellow at School of Law, Wuhan University, China. This research topic is supported by 'the Fundamental Research Funds for the Central Universities'. I sincerely appreciate the advice from the anonymous reviewer. In his or her opinion, it should be questioned whether the 1949 Hungarian Constitution is the first Constitution, considered that during the period of Hungarian Soviet Republic, there was a draft version of Constitution of Hungarian Soviet Republic in 1919 and in 1949, during the constitution-making in Hungary, there was a Draft Constitution of Hungarian People's Republic for widely discussion as well. See Halasz (2015) 36-7, Hörcher and Lorman (2019) 180-83. Hereby, the author accepted the opinion from the reviewer and revised the title with 'first written communist constitution', it refers to the first adopted and published written Constitution in Hungary and China. Besides, the reviewer pointed out a few of incorrect or vague descriptions in the article, I accepted and revised them. The author takes sole responsibility for his view.

1 Halász (2015) 29-37.

2 Mannino (1999) 8.

3 Chen (1999) 65. 
Hungary also adopted their own Constitution. In the Hungarian People's Republic (Magyar Népköztársaság), the first Constitution of Hungarian People's Republic was adopted in 1949, after the successful parliamentary election of Hungarian Working People's Party with the Hungarian Communist Party winning 285 seats. ${ }^{4}$ Therefore, there is no doubt that this Parliament adopted a Communist Constitution.

In this article, the author will firstly introduce how the socialist states adopted the Constitution and give a detailed examination of the text and structure of the Constitution separately, then a comparative work will present the major similarities and differences of the Constitution.

\section{THE FIRST WRITTEN COMMUNIST CONSTITUTION IN THE PEOPLE'S REPUBLIC OF CHINA}

In this part, the main focus will be on how the Chinese Communist Party set up a communist regime and tried to introduce a new Constitution which mainly followed on Soviet Union 1936 Constitution. What's more, in this part, the author will give an introduction of the first election of National People's Congress.

\subsection{Adoption of the Constitution of People's Republic of China}

The People's Republic of China was established on $1^{\text {st }}$ October 1949. Before the founding of the new China, the Chinese Communist Party abolished the previous legal system of the Republic of China and tried to set up its own legal system. In this part, the author will introduce how the National People's Congress elected its deputies and how the first written communist Constitution adopted by the National People's Congress in China.

\subsubsection{The First Election of National People's Congress in China}

According to the Organic Law of the Chinese People's Political Consultative Conference (hereinafter CPPCC), the CPPCC shall hold the plenary meeting in every three years. However, since the development of socialist transformation was much higher than it planned, the government was planned to hold the first election of people's congress in China and made the first Socialist Constitution of People's Republic of China. ${ }^{5}$

In February 1953, the Central People's Government Committee adopted the Electoral Law of People's Republic of China. Soon after, a nationwide census and voter registration took place in China. ${ }^{6}$ The census showed that there were $601,912,371$ people living in China and more than half of the Chinese population had the elective right.

According to the Electoral Law of 1953, people who are older than 18 years old shall enjoy the elective right, in Paragraph 1, Article 4 it stipulated that 'Every citizen of People's Republic of China who has reached the age of 18, irrespective of race, gender, occupation, family background, religious belief, education, property, length of residence, has the rights to vote and stand for election. ${ }^{7}$ In 1953, with the guidance of Electoral Law and people's enthusiasm, a nationwide grassroots election was held in China. Nearly 278 million people

${ }^{4}$ Hungarian Parliamentary Election, 1949 link 1.

5 Zhou (1999) 102-03.

6 Zhou (1999) 103. Zhang, Zeng (1979) 249.

7 Electoral Law of the National People's Congress and Local People's Congresses of the People's Republic of China of 1953 (expired), (2006) link 2. 
participated in this election procedure, $85.88 \%$ of the total voter, ${ }^{8}$ and $5,669,144$ deputies of county level People's Congress were elected. ${ }^{9}$

The Electoral Law regulated that the higher level's People's Congress were elected indirectly. ${ }^{10}$ The deputy of National People's Congress was elected by the provincial People's Congress. From July to August of 1954, 1,136 deputies of National People's Congress were elected by the deputies of provincial level; 60 deputies were elected by the military and 30 deputies were elected by overseas Chinese. ${ }^{11}$

The first election of National People's Congress was elected with 1,226 deputies in total, 668 deputies were Party member, while 558 deputies were not. It showed that during the first election of National People's Congress, the Communist Party had an open mind in this election. It ensured the diversity of a united front. ${ }^{12}$

Therefore, the legislature organ was formed when the first National People's Congress of People's Republic of China was held in September 1954 and during the first session of the meeting of National People's Congress, a Communist Constitution was adopted by these deputies.

\subsubsection{The Formation of the Constitution of People's Republic of China}

When the Chinese Communist Party took the highest power in mainland of China and passed the Common Program as a fundamental law in China, the leaderships in the Party realized a Constitution should be quickly adopted..$^{13}$ After the unification of mainland of China and successful socialist transformation, the leadership of the government agreed it is time to adopt a communist Constitution in People's Republic of China.

However, two years passed before the Constitution was adopted, Chinese leadership had a different idea of the Communist Constitution in China. In late 1952, before the finishing of the First CPPCC, the Chinese delegation visited Soviet Union for the $19^{\text {th }}$ Congress of the Communist Party of the Soviet Union and a letter from Chinese highest leadership was sent to Stalin. In this letter, it mentioned that China was planning to have a Socialist Constitution when the country would become a Socialist Society. ${ }^{14}$ Obviously Stalin had a very different view of this letter, he had a suggestion on the adoption a Chinese Constitution before the establishment of People's Republic of China and this time he gave his advice to the second most powerful person in Chinese Communist Party, Liu Shaoqi. His suggestion was China should adopt a Constitution soon, since a Constitution was the fundamental law in each country and the adoption of Constitution will legalize the leadership of Chinese Communist Party in People's Republic of China. The experiences from Hungary, Czechoslovakia and Poland had been learnt, through a nationwide election, the Chinese Communist Party would win this election and dominated in the Government. With the consideration of Stalin's suggestion, Chinese Communist Party decided to operate a nationwide election and prepared a new Constitution. ${ }^{15}$

8 Zhang, Zeng (1979) 249.

$9 \mathrm{Xu}(2003)$ 247-48. Zhou (1999) 103.

10 Electoral Law of the National People's Congress and Local People's Congresses of the People's Republic of China of 1953 (expired) (2006) link 2.

$11 \mathrm{Xu}(2003) 248$.

12 Zhou (1999) 103.

13 Zhang (2011) 281. Constitutionalism of New Democracy link 3.

14 Han (2004) 54-55.

15 Han (2004) 55-56. 
On 23 January of 1953, Constitution Drafting Committee was formed, not solely consisting of members of Chinese Communist Party, but also other Democratic Parties' members had the chance to join the Committee. ${ }^{16}$ Inside of the Chinese Communist Party, a Constitution Drafting Group was formed in January of 1954, immediately Mao Zedong and this Group left Beijing and went to Hangzhou and after two months, a draft version Constitution was accomplished. ${ }^{17}$

From 23 March of 1954 to 11 June 1954, there were seven meetings held by the Constitution Drafting Committee. At the same time, a wider discussion on the first Constitution was held by the Committee. The Constitution Drafting Committee organized 17 discussion groups, with nearly 8000 participants in the discussion resulting in over 5900 pieces of advice. After a good discussion, the draft version Constitution was published by the Central People's Government Committee. A nationwide discussion was soon organized in China and it was reported that more than 150 million Chinese participated in this unprecedented discussion. There were even organized Constitution propaganda teams by the local government. ${ }^{18}$

The eighth meeting of Constitution Drafting Committee was held on 8 September 1954, in order to adopt the Constitution, this draft Constitution should be passed by the Central People's Government Committee, this meeting lasted over 7 hours and finally in the end of the meeting, this draft Constitution was well examined and handed it in to the Central People's Government Committee. The next day, the draft Constitution was passed by the Central People's Government Committee and submitted to the National People's Congress. ${ }^{19}$

However, on the day before the meeting of People's National Congress, there were still two revisions of the draft Constitution brought by the Central People's Government Committee and they were considered as 'critical revise' regulation. The first one was in the Preamble, the third paragraph, it mainly changed the expression of this Constitution, in the original version, it from the 'our first Constitution' to 'The Constitution of People's Republic of China', since before this Constitution, there were 9 Constitutional documents published in China already. ${ }^{20}$ However, this Constitution was the first Constitution to the People's Republic of China. The second revision was stated in Article 3, Paragraph 3, which stated 'All the nationalities have the freedom to preserve or reform their own customs and

$16 \mathrm{Xu}(2003) 172$.

$17 \mathrm{Xu}(2003)$ 172-73.

$18 \mathrm{Xu}(2003)$ 233-34.

$19 \mathrm{Xu}$ (2003) 236-37.

20 The history of constitution-making in China begun at the late Qing Dynasty. The first constitutional document is Principles of the Constitution of 1908 which issued by the Qing Dynasty, it is believed that this Constitution was followed the outline of the Meiji Constitution. After the Xinhai Revolution, Qing Dynasty published its last constitutional document, the 19 Articles in 1911 and tried to save its governing in China. Later, the Republic of China drafted several constitutional documents. Namely, Provisional Constitution of the Republic of China (1912), Draft of the Constitution of the Republic of China (1913) or The Temple of Heaven Draft Constitution since the Constitution was read at the Temple of Heaven. Yuan Shikai promoted a new Constitution of People's Republic in 1914. Cao Kun became the President of Republic of China in 1923 and promoted its own Constitution, the Constitution of Republic of China (1923). During the Nanjing Nationalist Government, the Nationalist Party promulgated three constitutional documents, the Provisional Constitution of the Republic of China (1931), the Draft Constitution of Republic of China (1936) and the Constitution of Republic of China (1946). See, Zhang (2016) 77-330. The English version of the development of Chinese Constitution see. 
ways and religious belief.' Deputies from Tibet had a different view of 'reform their religious belief' and the revision resulted in these four words were deleted. ${ }^{21}$

The first National People's Congress was held in 15 September of 1954. In afternoon of the fifth day of the Congress meeting, the Deputies of the National People's Congress decided to vote for the Constitution of People's Republic of China using a secret ballot. There were 1197 Deputies presented in the voting, only 15 Deputies absented. The voting started in 16:45 in the afternoon and after 10 minutes voting procedure, the voting finished. After one-hour counting, the result of voting was announced, there were 1197 affirmative votes that also means all the Deputies agreed to adopted the Constitution. ${ }^{22}$

\subsection{Analysis of the Text and Structure of the Constitution of People's Republic of China}

It is very interesting to analyze the text and structure of the Chinese Constitution as the Chinese Constitution followed the model of 1936 Soviet Union. Before the draft Constitution version was completed, Mao Zedong sent a telegraph to the rest of the leadership who stayed in Beijing. In this telegraph, Mao mentioned:

'In order to have a better discussion (on the draft Constitution) among the politburo, it is advised to read such references...:

1. 1936 Soviet Union Constitution ...;

2. Russian Constitution of $1918 \ldots$;

3. The Constitution of Romania, Poland, Germany (German Democratic Republic) and Czechoslovakia, etc.... ${ }^{23}$

Liu Shaoqi and the rest of the leaderships who stayed in Beijing replied to this telegraph and studied the Constitution not only the Soviet Union one, but also the Constitution from the Eastern Bloc. Therefore, the Constitution of People's Republic of China had a strong influence from the earlier Constitution from Soviet Union and Eastern Bloc countries.

This is the first written communist Constitution in China consisting of five parts: A Preamble and four Chapters - 106 Articles in total. Also, just like the communist countries in East Europe, the Constitution of People's Republic of China has a very strong influence from the Stalin-Bukharin Constitution of 1936 (Hereinafter 1936 Soviet Constitution). Each level of People's Congress and the relationship between People's Congress and Administrative organs in each lever, which followed the Soviet Union's pattern. ${ }^{24}$

It is not practical to analyze each Article in this work, the most important text in each part of the Constitution will be examined. The Preamble part did not exist in every Communist Constitution, in the 1936 Soviet Constitution and Hungarian Constitution of 1949, there were no Preambles. However, in the Chinese Constitution, the Preamble was in the first part of the Constitution. Mao Zedong participated in the drafting period of each Article in the Constitution, even the Preamble part was the inspiration of Lenin's Declaration of Rights of The Working and Exploited People, when Mao read the Soviet Russian's Constitution documents. ${ }^{25}$

21 Han (2004) 389-92.

22 Han (2004) 393-94.

23 Han (2004) 68-70.

24 Frederick (2008) 104.

${ }^{25}$ Han (2004) 74-75. Declaration of Rights of The Working and Exploited People link 4. 


\subsubsection{The Preamble of the Constitution of People's Republic of China}

The Preamble had six paragraphs. The first paragraph mainly reviewed the Chinese revolutionary history and ensured the democratic system in China is people's democracy or new democracy. The second paragraph pointed out the current situation, a transition period, and the main task in this period is

'...Bring about the socialist industrialization of the country and, step by step, to accomplish the socialist transformation of agriculture, handicrafts and capitalist industry and commerce.'

The third paragraph addressed the Constitution was adopted by the First National People's Congress also mentioned the connection between the Common Program and the Constitution. The fourth paragraph emphasized the importance of people's democratic united front. The fifth paragraph mainly dealt with the all the nationalities in the territory of China, all the nationalities in China should be united in one great family with freedom and equality. The last paragraph focuses on the foreign affairs, People's Republic of China '... as already built an indestructible friendship with the great Union of Soviet Socialist Republics and the People's Democracies.' Also, China would like to develop an equal, mutual benefit relationship with each country in the world. ${ }^{26}$

\subsubsection{The General Principles of the Constitution of People's Republic of China}

The General Principles was the first Chapter in the Constitution. It consisted of 20 Articles and mainly dealt with the principles of ruling the country.

It could be concluded as the following six parts.

The first part was mainly defined the country's form and it clearly stated that People's Republic of China is a people's democratic state and 'All power in the People's Republic of China belongs to the people.' ${ }^{27}$ The second part was Article 3 and it mainly regulated the relationship of each nationality in China, also stating that China is a unitary multinational state. The third part was Article 4 and it dealt with the realizing the socialism. 'The Constitution of People's Republic of China in 1954 is not a complete socialist Constitution, it is a Constitution in the transition period'. ${ }^{28}$ The fourth part was mainly stipulated the economy system in China. At that time, the main task in economy system was transforming it from capitalism to socialism economy system. The fifth part was Article 16 and it emphasized the importance of work (or labor). The last part was mainly dealt with the importance of the masses of the people, the country should reply on the people, public servants should strive to serve the people and the armed forces of the People's Republic of China belong to the people and protect the fruits of the Revolution. ${ }^{29}$

\subsubsection{The State Structure of the Constitution of the People's Republic of China}

The second Chapter in the Constitution was the state structure of China, there were six sections in this Chapter. The first three parts of this Chapter regulated the powers and

${ }^{26}$ Han (2004) 85-86. Constitution of People's Republic of China in 1954 link 5.

27 Constitution of People's Republic of China in 1954 link 5.

28 Zhang, Zeng (1979) 252.

29 Constitution of People's Republic of China in 1954 link 5. 
responsibilities of central governing in People's Republic of China, that was the National People's Congress, the President of the People's Republic of China and State Council. The fourth part was mainly dealt with the local level governing organ, i.e. the local People's Congresses and the local People's Councils. The fifth part was the organs of self-government of national autonomous areas and the last one was the judicial system in China, the People's Courts and the People's Procuratorates.

\subsubsection{The Fundamental Rights and Duties of Citizens of the Constitution of People's Republic of China}

Chapter Three stipulated the fundamental rights and duties of citizens in China. There were 19 Articles in this Chapter and the first part, from Article 85 to Article 99 mainly regulated the rights of citizens of People's Republic of China, the second part, Article 100, 101,102 and 103 stipulated the duties of citizens of People's Republic of China and in the rights part not only stated the right of masses, but also emphasized the right of elder men, women, minors and overseas Chinese. ${ }^{30}$

In the Constitution of People's Republic of China, there were three different words related to the masses, however there are some difference between the following three words, 'people', 'citizen' and 'voter'. 'People' is more like a political concept and according to the Chairman Mao's article: 'Who are the people? they were the working class, the peasantry, the urban petty bourgeoisie and the national bourgeoisie. These classes, led by the working class and the Communist Party, unite to form their own state and elect their own government...' 31 'Citizen' is more of a legal concept, it refers the person who has Chinese citizenship, also in Mao's same article '...Landlord class and bureaucratbourgeoisie, as well as the representatives of those classes, the Kuomintang reactionaries and their accomplices...' these groups apparently not belong to the 'people', however even those persons are Chinese citizens. The concept of 'voter' is also different, according to the Article 86, the citizens who reached the age of 18 enjoyed the right of voting. 'Insane persons and persons deprived by law of the right to vote and stand for election' also did not have the right of voting. ${ }^{32}$

\subsubsection{The National Flag, National Emblem, Capital of Constitution of People's Republic of China}

This is the last Chapter of Constitution, there were three Articles in this Chapter and the first Article in this Chapter stated that 'red flag with five stars' is the national flag of People's Republic of China, red means the revolution and sacrifice, five stars symbolized the unite of the Chinese nationalities, the big star is the Chinese Communist Party. The second Article declared the national emblem of People's Republic of China and the last Article of the Constitution regulated the capital city of People's Republic of China, Beijing. However, there was not a national anthem which regulated in the Constitution. ${ }^{33}$

30 Constitution of People's Republic of China in 1954 link 5.

31 On the People's Democratic Dictatorship (2004) link 6.

32 Constitution of People's Republic of China in 1954 link 5. Han (2004) 250-51.

33 Constitution of People's Republic of China in 1954 link 5. 


\section{THE FIRST WRITTEN COMMUNIST CONSTITUTION IN THE HUNGARIAN PEOPLE'S REPUBLIC}

\subsection{Adoption of the Constitution of Hungarian People's Republic in 1949}

Hungary, a great power located in Central-Eastern Europe in history, especially after the Austro-Hungarian Compromise of 1867 . The Monarchy was generally considered as a great power in the World. ${ }^{34}$ In the past, Hungarian had its own historical constitution, the unwritten one, Hungarian Golden Bull was constituted in $1222 .{ }^{35}$ However, the first written Constitution of Hungarian People's Republic was not adopted by the National Assembly of Hungary until 1949. ${ }^{36}$

There is a very famous ancient saying in China that 'Take history as a mirror and you will understand why dynasties rise and fall. ${ }^{37}$ It could also apply the history of Hungary. Hungary had a very short experience of Soviet Republic, after the First World War, with the 'help' of the Soviet Russia, the Hungarian Communist Party founded the Hungarian Soviet Republic in Hungary. However, the Soviet Republic only lasted 133 days. ${ }^{38}$

History always presents similar plots to the audience. Following the Second World War, Hungary was 'liberated' by the Red Army in $1945 .{ }^{39}$ Hungary was independent but this country was mainly controlled by the Allied Control Council. In Hungary, the Communist Party was one of the most active Parties even though the Communist Party was not big. In November of 1945, the parliamentary election was held, however, the Smallholders Party won this election, it took 245 seats, account for $57 \%$ in total. ${ }^{40}$ Nevertheless, with the national wide propaganda, the Communist Party of Hungary gradually won the support from masses. In the Parliamentary election of 1947, in favor of the amended Electoral Law (Act 12 of 1947) and the financial support, Communist Party distributed over 4 million election posters and 10 million electoral leaflets and brochures among the country. On the voting day, the 'certified lists of names' also 'helped' the Communist Party to win the election. On 5 September 1947, the election result was released by the central electoral committee, the Communist Party took 100 seats and became the largest Party in the Parliament. ${ }^{41}$ Later, Parliamentary election in 1949, the Hungarian Working People's Party ${ }^{42}$ gained 285 seats. $^{43}$

By controlling the Parliament, Hungarian Working People's Party started its socialist transformation in the whole country. In 1948, as the Communist Party controlled Council of Ministers organized a Drafting Constitution Committee in order to lead this country from a capitalist to a socialist country. ${ }^{44}$ Soon, the Committee brought up a socialist Constitution to

34 Williamson Jr. (1991) 4.

35 Horcher and Lorman (2019) 16-23.

36 Sólyom-Fekete (1980) 192.

37 An Old Book of Tang, Wei Zheng Zhuan (2003) link 7.

38 Apor (2009) 1.

39 Zhelitski (1997) 73-74.

40 Zhelitski (1997) 76-78.

41 Izsak (2002) 106-17.

42 The Hungarian Working People's Party was formed by a merger of the Hungarian Communist Party and the Hungarian Social Democratic Party in June 1948. Csaba Fazekas, Sándor Fekete (2018) 41.

43 Hungarian Parliamentary Election, 1949 link1.

44 Halász (2015) 36. 
the Hungarian National Assembly, without any delays in the national legislature organ, the National Assembly adopted the Constitution of Hungarian People's Republic of 1949. Also, like other socialist countries in Central-Eastern Europe, even the world, the Hungarian 1949 Constitution was a very strongly influenced by the 1936 Soviet Constitution. ${ }^{45}$ William Sólyom-Fekete wrote in his article, 'the 1949 Constitution was a slavish imitation of the Soviet-type constitutions, with some variations resulting from the historical and political differences between the Soviet Union and Hungary.' 46

Constitution of Hungarian People's Republic in 1949 employed numerous regulations from the 1936 Soviet Constitution. It ensured the socialist system applied in the whole society. However, the 1949 Constitution had some very important amendments after its adoption, e.g., the 1972 and 1989 Constitutional Amendments. The 1949 Constitution was replaced by the new Constitution in 2011 .

\subsection{Analysis of the Text and Structure of the Constitution of Hungarian People's Republic in 1949}

The Constitution of Hungarian People's Republic in 1949 consisted of one Preamble and 11 Chapters. However, this could be subdivided into seven parts in order to make it easier to analyze. The first part was the Preamble, like most Communist Constitution at that time; the second part included Chapter One and Chapter Two, the Hungarian People's Republic and the Social Structure, it mainly presented the essential principles. The third part could be considered as the state structure. Chapter Three to Chapter Seven mainly regulated the provisions of state structure from central government to local authorities. The next part of the Constitution was fundamental rights and duties of citizens which was stipulated in Chapter Eight; Chapter Nine, Fundamental Electoral Principles could form the fifth part of the Constitution. The sixth part was Chapter Ten, the Emblem, Flag and Capital of the Hungarian People's Republic; the last part, also the seventh part was Chapter Eleven, Final Provision.

The following introduction of the text of the Constitution also will be presented in six parts not 11 parts (the 1949 Hungarian Constitution consisted of 11 Chapters). The first part of the Constitution was the Preamble. This was quite short when compared with the Preamble in the Chinese Constitution and it reviewed how the Soviet 'helped' Hungarians defeat German fascists and the so-called 'great landowners and capitalists'. It also clearly declared the leadership of work class and peasants in the new People's Republic. In the end of the Preamble, it also pointed out since the change of economic and social structure, Hungarian People's Republic adopted the new Constitution and indicated the future development of this country. ${ }^{47}$

The second part was the general principle of the Constitution. It included the first two Chapters in the Constitution. Chapter One in the 1949 Constitution was the definition of Hungarian People's Republic. It was not only pointed out that Hungary was a People's Republic, but also pointed out the all power of the State was belonged to the working people. It was a State of dictatorship of the proletariat. In the Chapter Two, which was named as The Social Structure, there were 6 Articles in this Chapter, it mainly focuses on

45 IBP USA (2013) 65-66.

46 Sólyom-Fekete (1980) 192.

47 Peaslee (1956) 185. Hungarian Version of Constitution of Hungarian People's Republic (1949). 
the economy structure in the 'new' society, capitalist economic system was gradually eliminated by the government, a socialist economic system would instead. In detail, the Article Four stipulated the owner of the bulk of means of the production, most of cases were owned by the public, however, it also allowed the private owner of means of production. In the next paragraph of Article Four, it stated that the power of force directing of national economy was belonged to the working people and pointed out the task, it was built socialist economic system instead of capitalist economic system. In the Article Five, showed the importance of the state national-economic plan. In the next Article, it regulated that all the natural and public resources belonged to the working people, however run by the State (government), Article Seven was related to the agrarian problem. The last two Articles in this Chapter mainly dealt with the labor issue. ${ }^{48}$

The third part in 1949 Hungarian Constitution included Chapter Three to Chapter Seven, it mainly dealt with the State structure. It could be divided into three sections: Central power, local power and judiciary power.

The first section in third part is central power which includes Chapter Three and Chapter Four. The Chapter Three stated that the highest organ of state authority is Parliament. The Parliament enjoyed variety state power, like legislature, determining the state budget, electing Presidential Council of People's Republic and the Council of Ministers and so on. Each term of Parliament shall be four years. However, in reality, it did not always follow the four-year term. Along with the Parliament, Presidential Council of People's Republic, which elected by the Parliament at its first sitting, was another important organ in the State authority, since the position of President was not available in the 1949 Hungarian Constitution. The Presidential Council of People's Republic partially enjoyed the power of President or Head of State, such as appoint diplomatic representatives and receiving the letters of credence of foreign diplomatic representatives, ratifying international treaties. The term of Presidential Council of People's Republic expired when the Parliament elected the new one. The member of Council of Ministers should not be elected as a member of Presidential Council of People's Republic. The other part of the central power was the highest organ of state administration, i.e. the Central Government or Council of Ministers of the Hungarian People's Republic. It was an executive organ in the highest organ system. Council of Ministers consisted of Chairman, Deputy Chairman, Minister of State and Minister of various Ministries and the member of the Council of Ministers was elected by the Presidential Council of People's Republic. There were 26 Ministries in the whole central government. In order to develop the socialist economy system, some Ministries were created, such as Ministry of State Farms and Forests, Ministry of Home Trade. The Council of Ministers empowered to issue decrees and decisions which did not infringe the laws of People's Republic, or decrees of Presidential Council of People's Republic. As a centralized State, the central authority and administration was empowered to annul or modify the regulations which made by the lower state power. ${ }^{49}$

The provisions of Local organs of State power were regulated in the Chapter Five. The main administration in the local level government was local council, different level councils governed its own administrative area. The local council was empowered to publish rules, regulations in its own area, which should not infringe the law or decrees from higher authorities, also it was possible to annual or modify the regulations which made by the lower level council in its own administrative area. The member of the local council was

48 Peaslee (1956) 185-86.

49 Peaslee (1956) 187-91. 
elected by voters with nomination by the Patriotic People's Front. The term of the council was four years. Executive Committee was the executive organ of the local council and had to responsible to the same level of council which elected it and to the executive committee of the superior council body as well. ${ }^{50}$

The judiciary section was mainly presented in Chapter Six and Chapter Seven. Chapter Six was mainly focus on the court. Supreme Court was the highest court in the People's Republic. All the judges were appointed. In according with communist system, the court of Hungarian People's Republic bore the task of 'punish the enemies of the working people'. ${ }^{51}$ The Public prosecutor was another important part of the judiciary system in Hungary. The main task of public prosecutor was observance of the law. Except the Chief Public Prosecutor was elected by the Parliament and responsible and accountable to the Parliament, other public prosecutors were appointed by the Chief Public Prosecutor.

The fourth part of the Constitution was the rights and duties of citizens. It was like other Communist States, the citizens enjoyed the rights of the education, labor and rest and freedom of religious worship. However, it should be noted that most of the rights were limited in order to in according with the communist system and the working class enjoyed more rights than others. In paragraph 1, Article 48, it stipulated that 'The Hungarian People's Republic ensures the rights to education for every worker. In the previous Article, it stated 'The Hungarian People's Republic protects the health of the workers and assists them in the event of sickness or disability'. Even the freedom of speech, press and assembly should be 'in accord with the interests of the workers' ${ }^{52}$

Electoral system was also important in the practice of communist political system in Hungarian People's Republic. Therefore, Chapter Nine mainly focuses on the election issue. The electoral provisions which regulated in the 1949 Hungarian Constitution almost contained the principles of election, excepted the 'excluding provision' which regulated in the Paragraph 2, Article 63, 'Enemies of the working people ...are excluded from the suffrage by law'. ${ }^{53}$

Chapter Ten regulated the coat of arms, the flag and the capital of the Hungarian People's Republic, the designation of the coat of arms and the flag were full of the characteristics of communist aesthetic.

The last Chapter was the final provisions. It included two Articles, mainly dealt with the time of enter into force, the enforcement subject and emphasized the most importance of the Constitution to the state power and the citizens. ${ }^{54}$

\section{COMPARATIVE ANALYSIS OF THE STRUCTURE AND TEXT OF THE FIRST WRITTEN COMMUNIST CONSTITUTION BETWEEN CHINA AND HUNGARY}

In the middle of 20th Century, after the Second World War, People's Republic of China and Hungary established the socialist system and started to adopt their first written communist Constitution, even the two Constitutions had a strong influence of 1936 Soviet Union Constitution, there were still some individualities in each Constitution. In this part, the author will employ a comparative analysis approach on the text and structure of the first

\footnotetext{
50 Antal (2010) 135.

51 Peaslee (1956) 191-93.

52 Peaslee (1956) 194-95.

53 Peaslee (1956) 196.

54 Peaslee (1956) 196.
} 
written Communist constitution between China and Hungary. By examining the differences and similarities of each State how they arrange the structure of the Constitution and employ the provisions in the Constitution, we could deduce the history background of constitutionmaking process and it also implied the development of the Constitution in the whole communist period in the respective countries.

\subsection{Comparative Analysis of Structure of the First Written Communist Constitution of China and Hungary}

After the destructive Second World War, newly independent States found there were two types of roads: capitalism and socialism. The Soviet Union was, at that time, the first and biggest Socialist State in the world. The Communist Party's propaganda, coalition of socialist group gradually won the leading position in Hungary, socialist road was nationwide spread in the country, meanwhile a communist Constitution was adopted by the legislature. Almost at the same time in East Asia, Chinese Communist Party with Chinese people just finished two wars, Anti-Japan War and Civil War. Chinese Communist Party won these wars and established its Socialist Regime. In order to legitimate the leadership of Communist Party, the first written Communist Constitution of People's Republic of China was adopted in 1954.

Even though China and Hungary established the Socialist Regime and adopted the Communist Constitution in their lands and all of these Constitutions patterned themselves on 1936 Soviet Union Constitution, different social condition and history made such differences in these Constitutions.

In the structure part, Constitution in the Hungary seemed more 'willing' to follow the 1936 Constitution's pattern.

There were 13 Chapters in the 1936 Soviet Union Constitution, the first two Chapters introduced the principles of the Republic; then introduced the central level State power; provisions of local level State power were stated in the following Chapter; the next Chapter stipulated the rules of Judiciary system in Soviet Union; Chapter Ten was fundamental rights and duties of citizens; Chapter Eleven provided the principles of electoral system; the last two Chapter were arms, flag, capital and procedure for amending the Constitution. ${ }^{55}$

The Constitution in Hungary almost followed this structure. The structure of the Constitution of People's Republic of China in 1954 was much simpler than Hungarian one. There were only four Chapters and one Preamble in the 1954 Chinese Constitution. However, examining the Chinese Constitution shows there were only two parts missed compared with 1936 Soviet Union Constitution and the Hungarian Constitution, that are the electoral system part and process of amending of Constitution part. Notwithstanding, the 1954 Chinese Constitution regulated some principles of electoral system in the National People's Congress and fundamental rights and duties of citizens parts.

Since the popularity of 'democratic centralism' 56 in Socialist States, the leadership of the States prefers a group of leadership. Therefore, in the 1936 Soviet Union Constitution

55 Constitution of the Union of Soviet Socialist Republics 1936 (2013) link 8.

56 The concept of 'democratic centralism'(民主集中制) is a general principle of organizing and decision-making process in the Chinese Constitution. It originally came from the Soviet Russia, Lenin mentioned the 'democratic centralism' should be carried out as 'an important, serious and extremely responsible task' link 9.In the decision-making process, the decision should be made by voting and it is binding on all the members of the organization. It is the core mechanism in Chinese political system link 10 . 
and the Hungarian Constitutions, the position of President of Republic is missed. However, there were provisions of President of Republic in the Chinese version. ${ }^{57}$ The reason for the difference could be considered that China was the major power against the Axis Powers in China battlefield in Second World War. After the Civil War in China, Chinese Communist Party not only won the war but also the support from masses. The leader of Chinese Communist Party Mao Zedong enjoyed the highest respect from the whole society. Therefore, when the Constitution of People's Republic of China in 1954 was adopted, he became the first Chairman (President) of the People's Republic. ${ }^{58}$

\subsection{Comparative Analysis of Text of the First Written Communist Constitution Between China and Hungary}

In this part, the text of the first written Communist Constitution in China and Hungary is analyzed. It is difficult to compare the text in the Constitution word by word. therefore, in this part, the author will mainly focus on the Preamble, fundamental rights and duties of citizens and the supreme organ of State power parts.

\subsubsection{Comparative Analysis of the Preamble of the First written Communist Constitution Between China and Hungary}

The 1936 Soviet Union Constitution did not include the Preamble part, however the Constitution of People's Republic of China in 1954 and the Hungarian Constitution in 1949 were included the Preamble part.

The Soviet Union was the 'big brother' in the Socialist world hence the two Constitutions mentioned the Soviet Union in the Preamble. By examining the speech related the Soviet Union, we could find the relationship between each State and Soviet Union. In Chinese case, Soviet Union was mentioned in the last paragraph of the Preamble, 'Soviet Union' and other 'People's Democracies' were friends of People's Republic of China, the relationship between China and Soviet Union was equal.

However, in the Hungarian case, the Preamble stated that 'The armed forces of the great Soviet Union liberated our country from the yoke of the German fascists...' in the first sentence.

The different level of 'importance' of the Soviet Union during the liberation period in the Second World War means that constitutional draftsman gave different attitudes to Soviet Union. For Hungary, according to the speech in the Preamble, the Soviet Union was a savior; however, for China, the Soviet Union was more like a true friend. These differences in the relationship between the Soviet Union and China and Hungary meant that the Soviet Union always supervised the reforms in Hungary and China split with Soviet Union in 1960s.

\subsubsection{Comparative Analysis of the Fundamental Rights and Duties of Citizens of the First Written Communist Constitution by China and Hungary}

Stipulating the fundamental rights and duties of citizens was a fad among Socialist States, which led by the 1936 Soviet Union Constitution. As a People's Republic, China also followed this trend. In the Constitution of People's Republic of China 1954, there was one

57 Constitution of People's Republic of China in 1954 link 5.

$58 \mathrm{Xu}(2003) 186,190 . \mathrm{Li}$ (2010) link11. 
Chapter to regulate the fundamental rights and duties of citizens. Meanwhile in Hungary, the drafting committee of Constitution also took such fad into account. ${ }^{59}$

By examining the fundamental rights and duties of citizens in the two Constitutions, it is easy to find the rights and duties which provided by Constitution were quite similar. Not only the scope of the rights and duties, but also the structure of rights and duties. Basically, the rights and duties of citizens which regulated in the 1936 Soviet Union Constitution could be found in the Constitutions of China and Hungary. For example, the first four fundamental rights of citizens in Soviet Union were related to the rights of work, leisure, assistance in sickness and disability of workers and education. Hungarian Constitution totally followed this order. All the Constitutions were designed to protect the freedom of speech, press, assembly, equality between man and woman, also the citizens were asked to defend of the State. There was no doubt that such high similarity among these Constitution on the issue of fundamental rights and duties of citizens, since the whole Constitution in China and Hungary had a strong influence of 1936 Soviet Union Constitution.

However, because of the unique social condition and history, there were some differences in the two Constitutions on the issue of fundamental rights and laws. 1936 Soviet Union Constitution regulated that '...citizens of the U.S.S.R. are ensured the right to unite in public organizations--trade unions...' ${ }^{60}$ Similarly, Constitution in Hungary also regulated these rights to their citizens. The only exception was Constitution of People's Republic of China, there was no similar provision on the right to organize trade unions. Even though, Trade Union Law of People's Republic of China was published in 1950. The public resources did not give us the reason why the 1954 Chinese Constitution deleted this right. Obviously, Trade Union did not play an important role in the history of People's Republic of China compared with Hungary. Also, since Constitution of People's Republic of China did not set one Chapter on the electoral system, universal suffrage was regulated in the Chapter of fundamental rights and duties of citizens.

\subsubsection{Comparative Analysis of the Supreme Organ of State Power of the First Written Communist Constitution of China and Hungary}

All the Communist Constitutions advocated that all the power of the State belongs to the (working) people in the very beginning part of the Constitution.61 Apparently, it was unrealistic to ensure everyone could perform their State power in practice. Therefore, the highest organ in the State, the organ which on behalf of the (working) people will exercise the State power. Notwithstanding, this organ should not be the Parliament, since according to the political philosophy of Marxism-Leninism, 'The Commune,' Marx wrote, 'was to be a working, not a parliamentary, body, executive and legislative at the same time....'62

Each Socialist States 'created' a supreme organ to carry out the State power on behalf of the (working) people, even though the name of this supreme organ of the State power in each country was different. In Soviet Union, it was Supreme Soviet of U.S.S.R; in People's Republic of China, it was National People's Congress; in Hungarian People's Republic, the

59 Constitution of People's Republic of China in 1954 link 5.

60 Constitution of the Union of Soviet Socialist Republics 1936 (2013) link 8.

${ }^{61}$ Constitution of People's Republic of China in 1954 link 5. Constitution of the Union of Soviet Socialist Republics 1936 (2013) link 8.

62 Lenin (1932) 39. 
Constitution named it as 'Országgyülés' (someone translated as National Assembly, some of them translated as Parliament). The examination of the name of the supreme organ of State power, it could find some preferences of the Constitutional draftsman during the process of Constitution making. The Communist Constitutions in Hungary followed their traditional name of Parliament, even their master of communism, Marx and Lenin declared to the whole world, Parliamentarism should be abolished. In China, the notion of People's National Congress was quite a novelty. The first time for 'National People's Congress' this phrase was in Constitution of Chinese Soviet Republic, a regional government in China in 1930s.

In spite of the supreme organ of the State power should play the same role as Parliament, it undertook the role of legislature, passed the annual State budget and elected the officers in different committees, etc. The supreme organ of State power in each State only held the short sessions per year. In Hungary, it was twice a year, in China, it was once per year. Therefore, a resident organization was needed for the daily political life. This resident organization almost entitled all the powers which the supreme organ of State power had, except some ultimate powers, such as amending the Constitution.

\section{CONCLUSIONS}

In this article, the first written Communist Constitutions in China and Hungary were introduced. After the Second World War, The Great Powers divided the political sphere in Europe. Soviet Union enjoyed the overwhelming influence in Eastern Europe, including Hungary. In the middle of $20^{\text {th }}$ century, Hungary established of the Socialist Sovereignties and published its Communist Constitution. Almost in the same time, in Eastern Asia, people from People's Republic of China witnessed the similar process in their State with the 'help' of Soviet Union.

Constitution is the fundamental law in modern States, by examining the Constitution, the ultimate system in the Sovereignty could be presented. The first written Communist Constitutions in China and Hungary presented their Soviet Union's style pattern. However, the different social conditions, especially in economic and political fields made each Constitution so unique. The author employed the comparative analysis method in this article, brought this conclusion on this comparative work: Hungary was much more under the supervision of Soviet Union compared with China. Therefore, the Constitutions in Hungary followed more Soviet patterns in its own Constitution. In the meantime, Hungary had a longer history of modern concept of democratic exercises. In certain sense, the regulations in the Constitution were more 'open' than the Chinese one and in fact the Constitution in Hungary had performed better than the Chinese one in practice.

\section{LITERATURE}

Antal, Tamas, 'Local soviets and councils in the Ex-socialist European States with special regard to Hungary (1950-1990)' (2010) 24 Hungarian Studies. 135-66.

Apor, Peter, Fabricating Authenticity 1919 and the Hungarian Communists between 1949 and 1959

(Doctoral dissertation, Debrecen University, 2009) <https://dea.lib.unideb.hu/dea/bitstream/ handle/2437/89593/tezis_angol.pdf;jsessionid=47AC29698439DD6C0B4795CC7024B186?seque nce $=6>$ accessed 23October 2019.

Chen, An, Restructuring Political Power in China: Alliances and Opposition, 1978-1998 (1st edn, Lynne Rienner Publishers 1999).

Cohen, Jerome Alan, 'China's changing constitution' (1978)76 The China Quarterly 794-841. 
Fazekas, Csaba, Fekete, Sándor, 'Historical Outline of the Development of the Hungarian Party System' (2018) 6 Review of History and Political Science. 36-46.

Frederick, Teiwes C., 'Establishment and Consolidation of the New Regime' in Macfarquhar, Roderick, Fairbank, John, K. (eds.), The Cambridge History of China, Vol. 14, The People's Republic, Part 1: The Emergence of Revolutionary China 1949-1965 (1st edn, Cambridge University Press 2008) 49-143.

Halász, Iván, 'The Institutional Framework and Methods of the Implementation of Soviet Legal Ideas in the Czechoslovakia and Hungary during Stalinism' (2015) 6 Journal on European History of Law 29-37.

Han, Dayuan, 1954 年宪法与新中国宪政 (The 1954 Constitution and the Constitutionalism of New China) (1st edn, Hunan People's Publishing House 2004).

Hörcher, Ferenc and Thomas Lorman (eds.) A History of the Hungarian Constitution: Law, Government and Political Culture in Central Europe (1stedn, I.B. Tauris 2019).

IBP USA, Hungary Country Study Guide, Volume 1 Strategic Information and Developments (2013 edn, International Business Publications 2013).

Izsák, Lajos, A Political History of Hungary, 1944-1990 (Andrew T. Ganetr, 1st edn, Eötvös University Press 2002).

Lenin V. I., State and Revolution (International Publishers 1932).

Mannino, Vito V., Cold War: When Did It Start? Why Did It Start (Bachelor thesis, Air University 1999).

Peaslee, Amos, J., Constitutions of Nations, Volume 2, Hungary (2nd ed. Springer 1956).

Sólyom-Fekete, William, 'Hungary' in Simons William B. (ed.) The Constitutions of the Communist World (1st edn, Springer 1980) 191-214.

Williamson Jr., Samuel, R., Austria-Hungary and the Origins of the First World War (1st edn, Palgrave Macmillan 1991).

Xu, Chongde, 中华人民共和国宪法史 (Constitution History of People's Republic of China) (1st edn, Fujian People's Publishing House 2003).

Zhang, Jinfan, Zeng, Xianyi, 中国宪法史略 (History of the Constitution of China) (1st edn, Beijing Publishing House 1979).

Zhang, Jinfan, 中国宪法史 (The History of Chinese Constitution) (1st edn, Jilin People's Publishing House, People's Publishing House 2011).

Zhang, Jinfan, 中国宪法史 (The History of Chinese Constitution) (Revised edn, China Legal Publishing House 2016).

Zhelitski, Bela, 'Postwar Hungary, 1944-1946' in Naimark, Norman, Gibianskii Leonid (eds.), The Establishment of Communist Regimes in Eastern Europe, 1944-1949 (1st edn, Westview Press, 1997) Chapter 4. <https://books.google.hu/books?id=EvZKDwAAQBAJ\&hl=zh-CN\&source= gbs_book_other_versions $>$, accessed 23 October 2019.

Zhou, Hong, 中华入民共和国国史通鉴 (The History of People's Republic of China), vol. 1, no.1 (1st edn, Contemporary China Publishing House 1999).

\section{LINKS}

1. The Results of Hungarian Parliamentary Election, 1949 is available <http://www.gutenberg.us/ articles/hungarian_parliamentary_election,_1949>, accessed 24 October 2019.

2. The Electoral Law of the National People's Congress and Local People's Congresses of the People's Republic of China of 1953 (expired) Chinese version is available <http://www.pkulaw. cn/fulltext_form.aspx?Gid=1244161>, accessed 24 October 2019.

3. The whole speech of Constitutionalism of New Democracy is available on $<$ https://www.marxists. org/chinese/maozedong/marxist.org-chinese-mao-19400220.htm>, accessed 24 October 2019.

4. Declaration of Rights of The Working and Exploited People is available $<$ https://www.marxists. org/archive/lenin/works/1918/jan/03.htm>, accessed 23 October 2019.

5. The English version of Constitution of People's Republic of China in 1954 is available $<\mathrm{http} / /$ en.pkulaw.cn/display.aspx?cgid=089435da920a5457bdfb\&lib=law >, accessed 23 October 2019.

6. Mao, Zedong, On the People's Democratic Dictatorship, is available <https://www.marxists.org/ reference/archive/mao/selected-works/volume-4/mswv4_65.htm>, accessed 24 October 2019. 
7. Take history as a mirror and you will understand why dynasties rise and fall. [以史为鉴, 可以知 兴替], Liu, Xu, An Old Book of Tang, Wei Zheng Zhuan, is available at <http://www.guoxue.com/ shibu/24shi/oldtangsu/jts 075.htm>, accessed 23 October 2019.

8. Constitution of the Union of Soviet Socialist Republics 1936, English version is available $<\mathrm{https}: / /$ constitutii.files.wordpress.com/2013/01/1936-en.pdf $>$, accessed 24 October 2019.

9. V. I. Lenin, Report on the Unity Congress of the R.S.D.L.P.: A Letter to the St. Petersburg Workers $<$ https://www.marxists.org/archive/lenin/works/1906/rucong/viii.htm>, accessed 22 October 2019.

10. Wang, Chuanzhi, 'Democratic Centralism: The Core Mechanism in China's Political System' (2013) 4 Qiushi Journal<http://english.qstheory.cn/politics/201311/t20131113_290377.htm>, accessed 22 October 2019

11. Li,Guihua，“存与废、虚与实: 新中国国家主席制度的变迁' [Existing or Abolishing, Virtual and Actual: the Changes of the Chairman system of People's Republic of China] (Beijing Daily, 6 September 2010) <http://dangshi.people.com.cn/GB/85040/12643464.html> accessed 24 October 2019. 
